\title{
Primary production and carbon uptake dynamics in the vicinity of South Georgia-balancing carbon fixation and removal
}

\author{
L. C. Gilpin ${ }^{1, *}$, J. Priddle ${ }^{2, * *}$, M. J. Whitehouse ${ }^{2}$, G. Savidge ${ }^{3}$, A. Atkinson ${ }^{2}$ \\ ${ }^{1}$ School of Life Sciences, Napier University, 10 Colinton Road, Edinburgh EH10 5DT, United Kingdom \\ ${ }^{2}$ British Antarctic Survey, Natural Environment Research Council, High Cross, Madingley Road, Cambridge CB3 0ET, \\ United Kingdom \\ ${ }^{3}$ Marine Laboratory, Queen's University Belfast, Portaferry, Co. Down BT22 1PF, United Kingdom
}

\begin{abstract}
Primary production was measured at a series of stations in austral summer 1996 in the vicinity of South Georgia. Five stations were occupied along a $700 \mathrm{~km}$ transect southeastwards towards the western tip of South Georgia. Three stations were located north of the Antarctic Polar Front (PF) with mean primary production of $0.41 \mathrm{~g} \mathrm{C} \mathrm{m}^{-2} \mathrm{~d}^{-1}$ compared to $0.54 \mathrm{~g} \mathrm{C} \mathrm{m}^{-2} \mathrm{~d}^{-1}$ for the stations south of the front. Three stations were in the shelf break and off-shelf region to the east of South Georgia where the lowest rates of primary production were recorded (mean $0.34 \mathrm{~g} \mathrm{C} \mathrm{m}^{-2} \mathrm{~d}^{-1}$ ). At a further 4 stations northwest of the island, primary production was significantly greater: 0.8 to $2.5 \mathrm{~g} \mathrm{C} \mathrm{m}^{-2} \mathrm{~d}^{-1}$ (mean $1.5 \mathrm{~g} \mathrm{C} \mathrm{m}^{-2}$ $\mathrm{d}^{-1}$ ). Photoinhibition was a marked feature of the production profiles, resulting in the underestimation of column production by 4 to $16 \%$. An assessment is made of the primary production required to maintain a representative assemblage of metazooplankton around South Georgia composed of $30 \mathrm{~g}$ fresh mass (FM) m $\mathrm{m}^{-2}$ krill and $20 \mathrm{~g} \mathrm{FM} \mathrm{m}^{-2}$ copepods. The total $\mathrm{C}$ requirement of both groups at maximum growth rate is estimated as $0.93 \mathrm{~g} \mathrm{C} \mathrm{m}^{-2} \mathrm{~d}^{-1}$, with $0.54 \mathrm{~g} \mathrm{C} \mathrm{m}^{-2} \mathrm{~d}^{-1}$ required to maintain basal metabolism (i.e. for zero growth). Local primary production rates are well in excess of the $\mathrm{C}$ demands for basal metabolism by the metazooplankton, and likewise the highest regional values exceed those for maximum metazooplankton growth. It is also estimated that the krill biomass required to sustain higher predators during their breeding season could be supported by local production at plausible maximum krill growth rate. In particular, high primary production found in this study to the northwest of South Georgia appears to be adequate to sustain maximum growth rate by krill when their biomass is $30 \mathrm{~g} \mathrm{FM}$ $\mathrm{m}^{-2}$, when krill production will exceed predator removal. It is already well known that advection from higher latitudes is important in supplying energy to the South Georgia system. This study adds to the evidence that locally enhanced primary production is also important in supporting the local food web.
\end{abstract}

KEY WORDS: Primary production · South Georgia · Southern Ocean · Photoinhibition · Nutrients · Carbon flux

\section{INTRODUCTION}

The Southern Ocean is a high nutrient low chlorophyll (HNLC) system, and its overall contribution to global oceanic carbon (C) fixation is only about onehalf of that expected from its area (Longhurst et al.

${ }^{*}$ Corresponding author: 1.gilpin@napier.ac.uk

${ }^{* *}$ Present address: Science Training and Education Partnership, Scolt House, 59 High Street, Barrington CB2 5QX, UK
1995, Priddle et al. 1998). A further feature of the Southern Ocean is the high degree of temporal and spatial heterogeneity in the distribution of phytoplankton biomass and production. High values (up to $30 \mathrm{mg}$ chlorophyll $a \mathrm{~m}^{-3}$ ) are often associated with specific physical and hydrographical features. These include neritic areas (Moline \& Prézelin 1997), the marginal ice-zone and polynyas (Smetacek et al. 1992, Smith \& Gordon 1997), and fronts and other mesoscale features (Heywood \& Priddle 1987, Savidge et al. 1995). 
In the Southern Ocean, enhanced phytoplankton biomass and production has been found consistently near several Antarctic and sub-Antarctic islands (Perissinotto et al. 2000, Blain et al. 2001), including South Georgia (Whitehouse et al. 1999, 2000). Satellite imagery further shows that high chl a concentrations can extend far downstream of the island (Atkinson et al. 2001). The increased phytoplankton production in this region is of major ecological significance, being associated with a productive food web and valuable commercial fisheries. This has been known for many years (Hardy \& Gunther 1935) but the mechanisms for the high productivity have remained unclear (Atkinson et al. 2001). A central question is whether the higher predators at South Georgia depend mainly on locally enhanced primary production and fluxes through the food web, or rather on the Antarctic Circumpolar Current (ACC) in transporting food into their foraging areas. Recent interpretations (Murphy 1995, Murphy et al. 1998) have emphasised the role of advection, although Atkinson et al. (2001) also stressed the importance of enhanced local food web fluxes.

A better understanding of this problem requires a quantification of locally produced $\mathrm{C}$ from primary production. There have been surprisingly few estimates of primary production near South Georgia, and these are from a variety of approaches, some indirect, such as nutrient deficits (Whitehouse et al. 1996), nitrogen uptake (Owens et al. 1991) and oxygen flux measurements (Blight 1997). Only Pakhomov et al. (1997b) have made measurements of primary production with the ${ }^{14} \mathrm{C}$ method, and obtained regional coverage near South Georgia.

In this paper, we present primary production data obtained using the ${ }^{14} \mathrm{C}$ technique from the on-shelf, off-shelf and oceanic waters to the north of South Georgia. Firstly, the rates are compared with those from elsewhere in the Antarctic Zone of the Southern Ocean to examine the degree and areal extent of the enhanced productivity. Secondly, in the context of the local food web, we make simple comparisons between the primary production values and the measured consumption rates of higher trophic levels, to examine whether the elevated primary production at South Georgia might enhance food web fluxes sufficiently to support the higher predators.

\section{STUDY SITE}

South Georgia is an island with an extensive shelf, forming part of the Scotia Ridge, a mainly submarine island arc bounding the Scotia Sea to the north, east and south. It lies $>200 \mathrm{~km}$ south of the Polar Front (PF), and is influenced directly by the Southern ACC Front, and sometimes by high latitude waters that bring cold, silicate-rich waters to the north of the island (Trathan et al. 1997, Brandon et al. 1999, Whitehouse et al. 2000, Atkinson et al. 2001).

\section{METHODS}

Data presented here derive from cruise JR11 of RRS 'James Clark Ross' in January-February 1996. The cruise forms part of a long series of studies by the British Antarctic Survey (BAS) around South Georgia, and was the first of a $5 \mathrm{yr}$ programme investigating interannual variability. The present investigation is based on data from 12 stations (Fig. 1). Five stations were occupied along a transect from north of the Maurice Ewing Bank at $47^{\circ} 59^{\prime} \mathrm{N}, 43^{\circ} 16^{\prime} \mathrm{W}$ southeastwards across the PF towards the western tip of South Georgia; 4 were sampled from the shelf break and off-shelf regions to the northwest of South Georgia, while the remaining 3 stations were sampled to the northeast of the island.

Water samples were obtained from 101 GoFlo bottles mounted on a rosette sampler, integral with a Neil Brown Mk IIIB CTD system. Samples to be used for the estimation of chlorophyll a ( $\mathrm{chl}$ a) and nutrient concentrations were taken within approximately $1 \mathrm{~h}$ of local

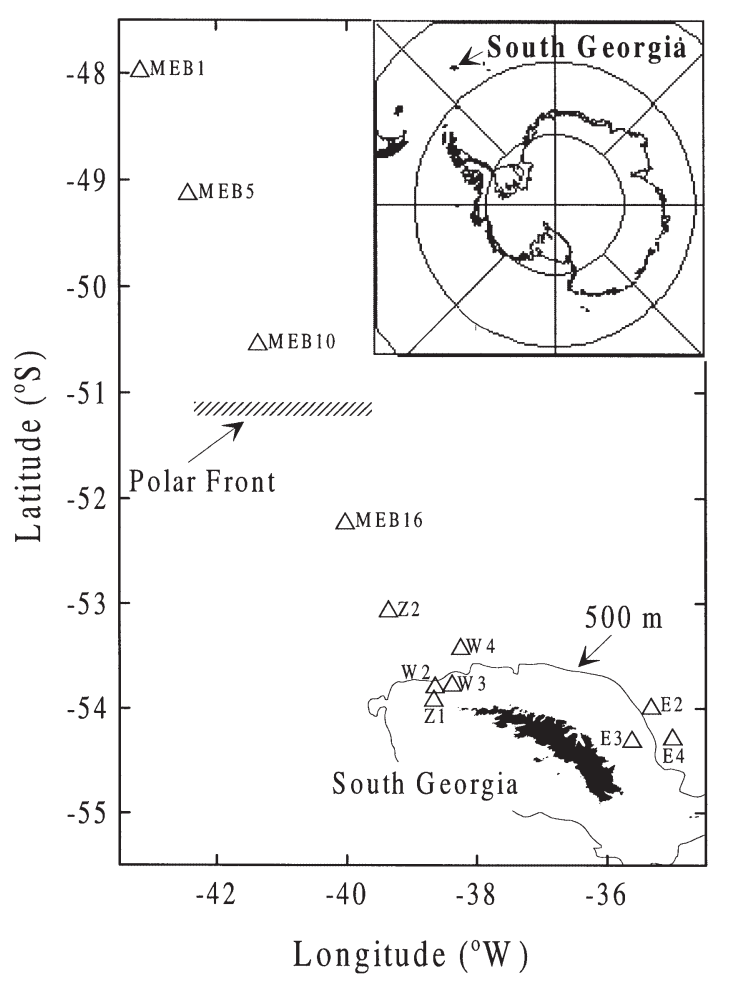

Fig. 1. Study area indicating the 12 primary production stations in the vicinity of South Georgia 
dawn at depth intervals of between 10 and $20 \mathrm{~m}$ to around $100 \mathrm{~m}$ and then at selected intervals to $200 \mathrm{~m}$. Chl a concentrations were determined fluorometrically following overnight extraction of the sample in $90 \%$ acetone in a refrigerator (Parsons et al. 1984) and nutrients were measured colorimetrically (Whitehouse 1997)

Samples to be used for the productivity estimates were collected from the surface mixed layer at a depth of approximately $40 \mathrm{~m}$ from the same CTD cast as the chl $a$ and nutrient samples. Productivity was estimated using the ${ }^{14} \mathrm{C}$ technique and deck incubations (see Savidge \& Gilpin 1999). Aliquots from the initial sample were dispensed into $60 \mathrm{ml}$ polycarbonate bottles to each of which was added $10 \mu \mathrm{Ci}$ of $\mathrm{NaH}^{14} \mathrm{CO}_{3}$. Triplicate bottles were incubated on deck in shaded Perspex tubes at $97,55,33,20,14,7,5,3,2$ and $1 \%$ of ambient irradiance, with the tubes cooled by flowing surface seawater. The samples were incubated for $24 \mathrm{~h}$, and the flux of photosynthetically active radiation (PAR) was measured continuously by a Didcot DRP1 sensor mounted on the ship's foremast. At night, the tubes were covered in black polythene or the samples placed in a coldroom in a dark box to avoid interference from deck lighting. Following incubation, each sample was filtered under low vacuum through a $0.2 \mu \mathrm{m}$ polycarbonate (Nuclepore) filter, fumed for 10 min over $\mathrm{HCl}$, desiccated for several days and stored under cool, dark conditions. On return to the laboratory, $2.5 \mathrm{ml}$ of Optiphase Hisafe III scintillation fluid was added to each filter and ${ }^{14} \mathrm{C}$ fixation established using an LKB scintillation counter. A triplicate set of dark incubations was carried out at each station and the average value was used to correct the light uptake data. Additions of ${ }^{14} \mathrm{C}$ were standardised for each experiment.

This method is based on accepted JGOFS protocols. The duration of the incubation leads to the estimation of net rather than gross production owing to the heterotrophic activity occurring in the bottles. However, in this study this was appropriate since the proportion of primary production available to higher trophic levels was required for subsequent budget calculations.

The corrected uptake data were integrated over the euphotic zone (1\% light depth) to provide production values at the 12 stations. Irradiance profiles were not obtained during the cruise and so a comparison was made of PAR attenuation values derived from the empirical equations of Fenton
(1991), Fenton et al. (1994), Mitchell \& Holm-Hansen (1991) and Dierssen et al. (2000). The relationship of Fenton (1991) for South Georgia inshore waters and deeper waters offshore to the north $\left(K d_{\mathrm{PAR}}=\right.$ 0.0072 [chl a concentration] +0.0756; $\mathrm{r}^{2}=0.795, \mathrm{n}=8$ ) was used to estimate the euphotic zone depth at each station. Table 1 indicates that the estimates derived using the relationships of the other workers were shallower by an average of $9 \%$ (Mitchell \& Holm-Hansen 1991), deeper by an average of $27 \%$ (Fenton et al. 1994), or varied around the current euphotic depths with an average deviation of $15 \%$ (Dierssen et al. 2000).

\section{RESULTS}

\section{Transect stations north of the PF}

The PF was located between Stns MEB10 and MEB16 along the transect (Trathan et al. 2000). Surface temperature values at Stns MEB1, MEB5 and MEB10 ranged between $7.85^{\circ} \mathrm{C}$ at MEB1 and $5.61^{\circ} \mathrm{C}$ at MEB10 (Table 2). Density was controlled by temperature in the surface water and a shallow surface mixed layer, deepening from $20 \mathrm{~m}$ at MEB1 to $38 \mathrm{~m}$ at MEB10 (Table 2, Fig. 2) was evident at all 3 stations. Surface silicate ( $\mathrm{Si}$ ) concentrations were low, in the range 2 to $6 \mathrm{mmol} \mathrm{m}{ }^{-3}$, with nitrate $\left(\mathrm{NO}_{3}\right)$ concentrations of the

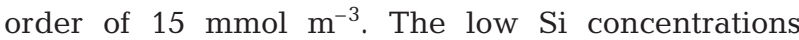
together with the physical properties characterise the presence of sub-Antarctic surface water (SAW) at these locations. Chl a concentrations in the surface

Table 1. Comparison of the $1 \%$ light depths estimated using the $K d_{\mathrm{PAR}}$ vs chlorophyll relationships of Mitchell \& Holm-Hansen (1991), Fenton et al. (1994) and Dierssen et al. (2000) with the $1 \%$ LDs used in the text as derived using data from Fenton (1991)

\begin{tabular}{|lccr|}
\hline Stn & $\begin{array}{c}\text { \% deviation of estimated 1\%LD from value derived } \\
\text { Mitchell \& Holm- } \\
\text { Hansen (1991) }\end{array}$ & $\begin{array}{c}\text { Fenton } \\
\text { et al. (1994) }\end{array}$ & $\begin{array}{r}\text { Fenton (1991) } \\
\text { Dierssen } \\
\text { et al. (2000) }\end{array}$ \\
\hline MEB1 & 7.05 & -29.81 & -3.30 \\
MEB5 & 7.55 & -29.07 & 0.76 \\
MEB10 & 7.12 & -29.72 & -2.74 \\
MEB16 & 9.38 & -26.43 & 11.36 \\
Z2 & 5.95 & -31.43 & -15.45 \\
Z1 & 10.58 & -24.70 & 16.13 \\
W4.1.N & 16.05 & -16.80 & 28.26 \\
W3.1.S & 11.25 & -23.72 & 18.33 \\
W2.1.S & 17.30 & -15.01 & 29.80 \\
E2.1.N & 5.33 & -32.31 & -25.60 \\
E3.1.S & 7.18 & -29.62 & -2.21 \\
E4.1.N & 5.26 & -32.41 & -26.97 \\
Average ${ }^{a}$ & 9.17 & 26.75 & 15.08 \\
${ }^{a}$ Calculated ignoring the sign of the deviation & \\
\hline
\end{tabular}


Table 2. Physical and biological characteristics of the productivity stations: position, surface temperature, depth of surface mixed layer (as defined by depth of initial $0.05 \sigma_{\mathrm{t}}$ change in density) and euphotic zone, typical mixed layer (ML) concentration of dissolved reactive silicate, nitrate, ammonium and chl a

\begin{tabular}{|c|c|c|c|c|c|c|c|c|c|c|}
\hline Region & Stn & $\begin{array}{c}\text { Latitude } \\
\left({ }^{\circ} \mathrm{S}\right)\end{array}$ & $\begin{array}{l}\text { Longitude } \\
\qquad\left({ }^{\circ} \mathrm{W}\right)\end{array}$ & $\begin{array}{c}\text { Surface } \\
\text { temp } \\
\left({ }^{\circ} \mathrm{C}\right)\end{array}$ & $\begin{array}{c}\text { Mixed } \\
\text { layer -ML } \\
(\mathrm{m})\end{array}$ & $\begin{array}{l}\text { Euphotic } \\
\text { zone } \\
\text { (m) }\end{array}$ & $\begin{array}{c}\text { ML } \\
\text { silicate } \\
\left(\mathrm{mmol} \mathrm{m}^{-3}\right)\end{array}$ & $\begin{array}{c}\text { ML } \\
\text { nitrate } \\
\left(\mathrm{mmol} \mathrm{m}^{-3}\right)\end{array}$ & $\begin{array}{c}\text { ML } \\
\text { ammonium } \\
\left(\mathrm{mmol} \mathrm{m}^{-3}\right)\end{array}$ & $\begin{array}{c}\mathrm{ML} \\
\mathrm{chl} \mathrm{a} \\
\left(\mathrm{mg} \mathrm{m}^{-3}\right)\end{array}$ \\
\hline \multicolumn{11}{|c|}{ Transect $\mathbf{N}$ of $\mathbf{P F}$} \\
\hline & MEB1 & -47.96 & -43.18 & 7.85 & 20 & 58 & 2.4 & 18.87 & 0.4 & 0.57 \\
\hline & MEB5 & -49.11 & -42.44 & 5.54 & 32 & 57 & 6.5 & 17.16 & 0.38 & 0.65 \\
\hline & MEB10 & -50.52 & -41.37 & 5.61 & 38 & 58 & 2.9 & 15.54 & 0.66 & 0.58 \\
\hline \multicolumn{11}{|c|}{ Transect $\mathrm{S}$ of $\mathrm{PF}$} \\
\hline & MEB16 & -52.21 & -40.02 & 3.68 & 55 & 56 & 9.5 & 18.7 & 0.69 & 0.96 \\
\hline & $\mathrm{Z} 2$ & -53.05 & -39.36 & 4.69 & 58 & 59 & 0.56 & 18.91 & 0.95 & 0.4 \\
\hline \multicolumn{11}{|c|}{ W shelf break } \\
\hline & Z1 & -53.90 & -38.67 & 2.98 & 58 & 55 & 21.9 & 20.83 & 1.11 & 1.18 \\
\hline & W4 & -53.40 & -38.25 & 3.28 & 45 & 50 & 10.1 & 17.41 & 0.43 & 2.40 \\
\hline & W3 & -53.75 & -38.38 & 3.17 & 35 & 54 & 21.7 & 18.76 & 1.36 & 1.31 \\
\hline & W2 & -53.77 & -38.65 & 2.99 & 40 & 48 & 21.8 & & 0.83 & 2.74 \\
\hline \multicolumn{11}{|c|}{ E shelf break } \\
\hline & E2 & -53.97 & -35.33 & 1.94 & 60 & 59 & 30.0 & 25.79 & 1.22 & 0.31 \\
\hline & E3 & -54.29 & -35.62 & 2.30 & 50 & 58 & 25.3 & 21.73 & 1.61 & 0.59 \\
\hline & E4 & -54.27 & -35.00 & 1.91 & 60 & 59 & 31.9 & 24.69 & 0.6 & 0.30 \\
\hline
\end{tabular}

mixed layer were typically $0.6 \mathrm{mg} \mathrm{m}^{-3}$ at each station (Table 2), with these concentrations extending to depths of between 60 and $100 \mathrm{~m}$ (Fig. 2). A mean value of primary production $0.41 \mathrm{~g} \mathrm{C} \mathrm{m}^{-2} \mathrm{~d}^{-1}$ was recorded for these transect stations (Fig. 3).

\section{Transect stations south of the PF}

At Stns MEB16 and Z2, the vertical temperature profile exhibited a distinct subsurface minimum (mean $0.71^{\circ} \mathrm{C}$, Fig. 2) associated with the winter surface mixed water (Whitehouse et al. 1996). The density profile in the upper $80 \mathrm{~m}$ at the 2 stations essentially reflected the temperature profile with the principal surface mixed layer extending down to approximately $60 \mathrm{~m}$ (Fig. 2). At depths greater than $80 \mathrm{~m}$, density increased monotonically, closely reflecting changes in salinity. Surface Si concentrations of approximately $10 \mathrm{mmol} \mathrm{m}^{-3}$ were recorded at MEB16 but a marked decrease to $0.56 \mathrm{mmol} \mathrm{m}^{-3}$ was recorded at $\mathrm{Z} 2$ (Table 2). The decrease was assumed to be indicative of active diatom growth at this location. The corresponding $\mathrm{NO}_{3}$ concentrations increased slightly to $18.7 \mathrm{mmol} \mathrm{m}^{-3}$ south of the PF. There was a marked subsurface ammonium $\left(\mathrm{NH}_{4}\right)$ concentration maximum in the range 1 to $2 \mathrm{mmol} \mathrm{m}^{-3}$, with corresponding surface concentrations between 0.4 and $1.0 \mathrm{mmol} \mathrm{m}^{-3}$.

$\mathrm{Chl}$ a concentrations in the surface mixed layer were in the range 0.4 to $1.0 \mathrm{mg} \mathrm{m}^{-3}$ (Table 2). In contrast to transect stations to the north of the $\mathrm{PF}$, the southern stations had a pronounced subsurface chl a maximum (SCM) located some $10 \mathrm{~m}$ below the base of the surface mixed layer (Fig. 2) with concentrations at least double those observed in the surface layer. The presence of SCMs has been reported from the Southern Ocean (Yamaguchi et al. 1985, Whitehouse et al. 2000, Wright \& van den Enden 2000) whereas Whitehouse et al. (1993) remarked specifically on the absence of SCMs in South Georgia waters during 3 summer surveys. The reasons for the presence or absence of SCM are not clear since there was no evidence of a more sharply defined pycnocline or of reduced vertical mixing at either station compared to other stations studied during the cruise. The depth of the euphotic zone was comparable to that of the mixed layer (Table 2) indicating that active phytoplankton growth was not occurring in the SCM and that it may have resulted from sedimentation. Subsurface ammonium maxima were generally located below the SCM, suggesting that they were generated by the remineralisation of organic matter sedimenting from the SCM. The mean rate of primary production recorded for these stations was $0.54 \mathrm{~g} \mathrm{C} \mathrm{m}^{-2} \mathrm{~d}^{-1}$, slightly higher than that to the north of the PF (Fig. 3).

\section{Western shelf break area}

At Stns W4, W3, W2 and Z1, a subsurface temperature minimum was present between 80 and $110 \mathrm{~m}$, with temperatures in the range 0.24 to $0.41^{\circ} \mathrm{C}$ (Fig. 2). A surface mixed layer extending down to approxi- 


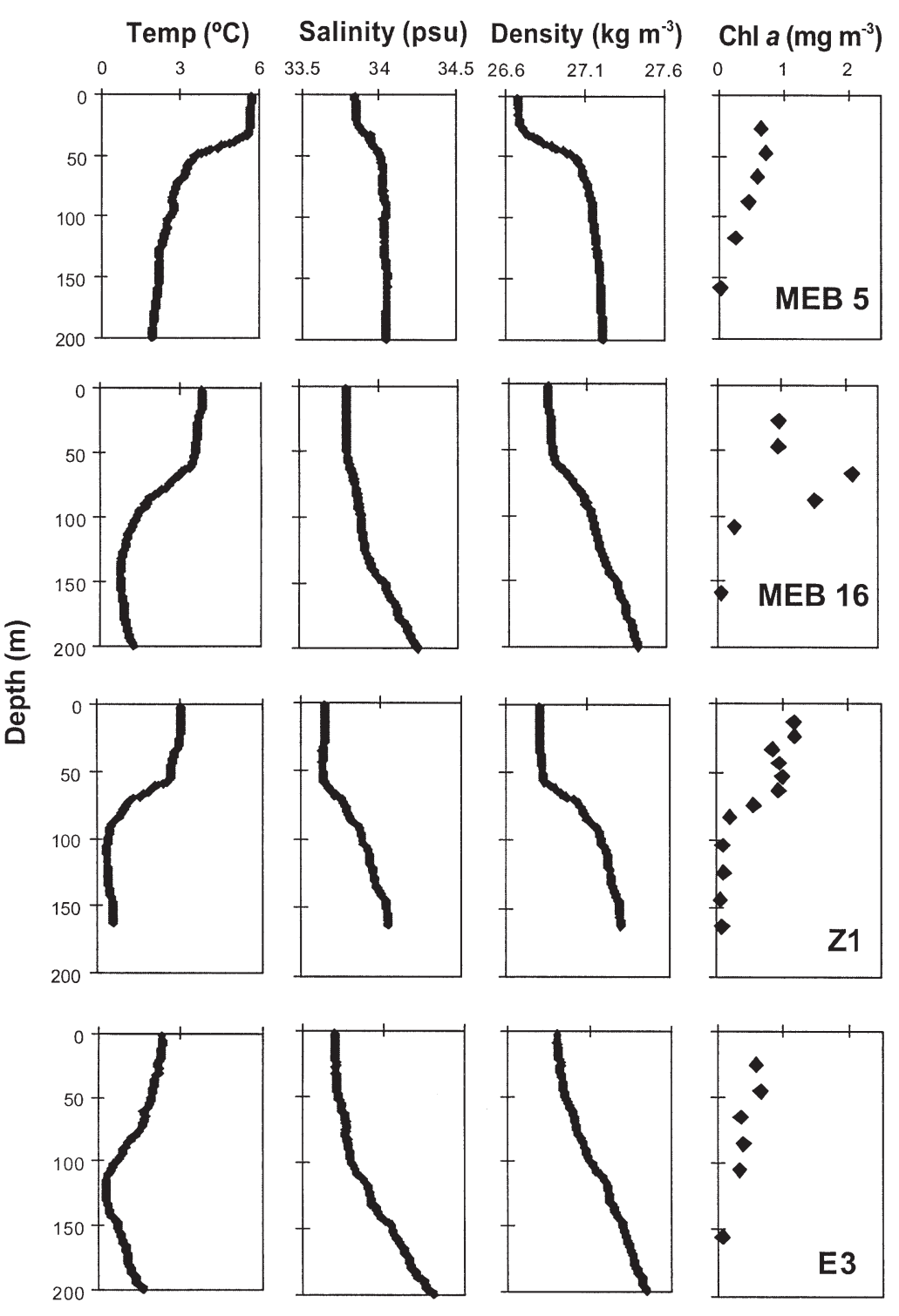

Fig. 2. Vertical distribution of potential temperature, salinity, potential density $\left(\sigma_{t}\right)$ and chl a concentration at stations representative of the 4 regions described in this study

mately $30 \mathrm{~m}$ was present at all stations. Between approximately 30 and $60 \mathrm{~m}$, a complex density structure was evident with a density gradient $>0.1 \sigma_{\mathrm{t}}$ units at the $3 \mathrm{~W}$ stations, although density increased by only $0.03 \sigma_{\mathrm{t}}$ units at Stn Z1 (Fig. 2).

Surface $\mathrm{Si}$ and $\mathrm{NO}_{3}$ concentrations were high at the 4 stations at around 20 and $17 \mathrm{mmol} \mathrm{m}^{-3}$, respectively, except at W4 where the Si concentration was $10 \mathrm{mmol}$ $\mathrm{m}^{-3}$ (Table 2). $\mathrm{NH}_{4}$ concentrations were maximal in the surface mixed layer and were generally in the range 1.0 to $1.5 \mathrm{mmol} \mathrm{m}^{-3}$. At the majority of stations, the high $\mathrm{NH}_{4}$ values extended well below the surface mixed layer, suggesting active remineralisation of organic material sedimenting out of the surface layer. The highest surface chl a concentrations of the cruise were all from this region, with values in the range 1.18 to $2.74 \mathrm{mg} \mathrm{m}^{-3}$ (Table 2). Concentrations either decreased steadily with depth from the surface to $100-150 \mathrm{~m}$, as observed at Stns W4 and W3, or decreased rapidly below $60 \mathrm{~m}$, as at W2 and Z1. Primary production in this region was the highest recorded during the cruise, with a mean value of $1.52 \mathrm{~g} \mathrm{C}$ $\mathrm{m}^{-2} \mathrm{~d}^{-1}$ (Fig. 3).

\section{Eastern shelf break area}

Although a marked subsurface temperature minimum averaging $0.07^{\circ} \mathrm{C}$ was present at Stns E2, E3 and E4, the density profile reflected the salinity profile, with a surface mixed layer extending down to approximately $40 \mathrm{~m}$ (Fig. 2). Surface Si concentrations at all 3 stations were in the range 25 to $32 \mathrm{mmol} \mathrm{m}^{-3}$ (Table 2) while $\mathrm{NO}_{3}$ concentrations were in the range 20 to $25 \mathrm{mmol} \mathrm{m}^{-3}$. $\mathrm{NH}_{4}$ concentrations at E2 and E3 were high in the upper $100 \mathrm{~m}$ (1.0 to $1.6 \mathrm{mmol} \mathrm{m}^{-3}$ ), decreasing to $<0.1 \mathrm{mmol} \mathrm{m}^{-3}$ at $200 \mathrm{~m}$. A similar distribution was also evident at E4, although surface concentrations were lower with a mean of $0.6 \mathrm{mmol} \mathrm{m}^{-3}$ $\mathrm{NH}_{4}$. The generally high $\mathrm{NH}_{4}$ concentrations in the surface layer at these stations suggest an excess of organic nitrogen remineralisation over $\mathrm{NH}_{4}$ uptake in this horizon. Surface chl a concentrations, ranging between 0.3 and $0.6 \mathrm{mg} \mathrm{m}^{-3}$ (Table 2), were evenly distributed throughout the mixed layer, with no SCM evident. Beneath the mixed layer, chl a concentrations decreased steadily to depths between 100 and $150 \mathrm{~m}$. Primary production was low, with a mean value of $0.34 \mathrm{~g} \mathrm{C} \mathrm{m}^{-2} \mathrm{~d}^{-1}$ (Fig. 3).

Column production at the survey stations ranged from 0.18 to $2.48 \mathrm{~g} \mathrm{C} \mathrm{m}^{-2} \mathrm{~d}^{-1}$, with the highest values being found in the western shelf break area and lowest values in the eastern shelf break (Fig. 3). The relationship between column production $P\left(\mathrm{~g} \mathrm{C} \mathrm{m}^{-2} \mathrm{~d}^{-1}\right)$ and column chl a $\left(\mathrm{mg} \mathrm{m}^{-2}\right)$ using all available station data was $\mathrm{p}=0.0113 \mathrm{chl} a, \mathrm{r}^{2}=0.35, \mathrm{n}=11$. However, Stn MEB16 lay off the line of best-fit and its removal yielded an $\mathrm{r}^{2}$ of $0.62 ; \mathrm{p}=0.0139 \mathrm{chl} a$ (Fig. 4) suggest- 


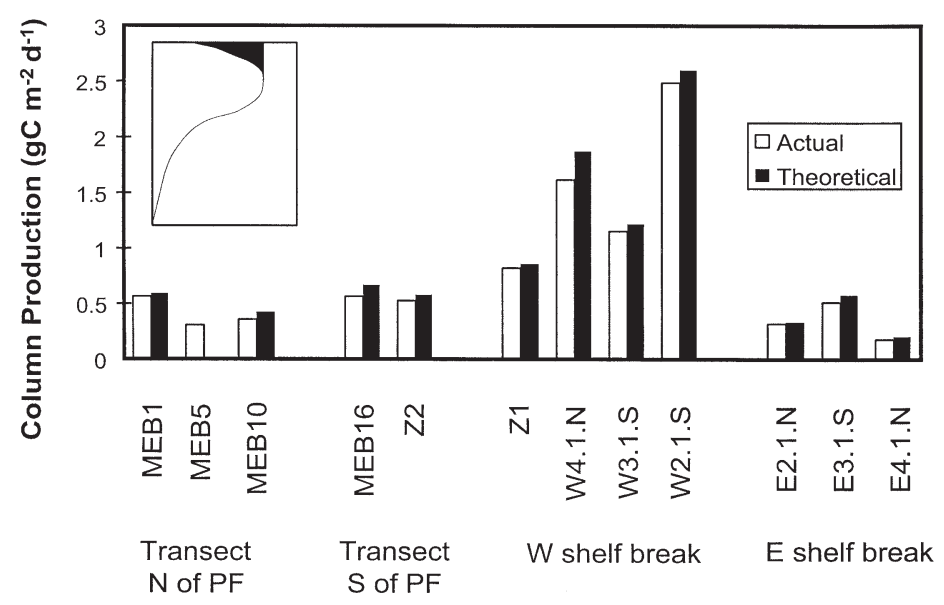

Fig. 3. Column production derived from actual data including photoinhibition and from theoretical calculations using $P_{\max }$ and assuming no photoinhibition. Stations grouped for each region as discussed

ing that primary production was closely related to phytoplankton biomass. Similar conclusions were derived indirectly by Mathot et al. (1992) for samples taken from ACC water along meridional transects at $47^{\circ} \mathrm{W}$ and $49^{\circ} \mathrm{W}$.

\section{DISCUSSION}

\section{Primary production measurements in a regional context}

The range of primary production measured during this survey encompasses all previous estimates for the region. Values from earlier studies, using a range of techniques, vary from 0.1 to $1.9 \mathrm{~g} \mathrm{C} \mathrm{m}^{-2} \mathrm{~d}^{-1}$ (Owens et al. 1991, Priddle et al. 1995, Blight 1997, Pakhomov et al. 1997b). The value of 30 to $40 \mathrm{~g} \mathrm{C} \mathrm{m}^{-2} \mathrm{yr}^{-1}$ for annual production inferred by Whitehouse et al. (1996) from differences between winter and summer nutrient concentrations suggests that average primary production rates for the South Georgia zone tend to be at the lower end of the range of measured daily rates. However, their estimate should probably be taken as a minimum value as no additional nutrient input to the system was assumed during summer.

Only a limited number of direct estimates of primary production have been made previously in the water masses encountered during the present survey, making comparison difficult. The mean value recorded on the transect to the north of the PF $\left(0.41 \mathrm{~g} \mathrm{C} \mathrm{m}^{-2} \mathrm{~d}^{-1}\right)$ is higher than that re-calculated from Allanson et al. (1981) for January 1981 from the SAW for longitude $20^{\circ} 24^{\prime} \mathrm{E}\left(0.13 \mathrm{~g} \mathrm{C} \mathrm{m}^{-2} \mathrm{~d}^{-1}\right)$ assuming an $18 \mathrm{~h}$ irradiance day. Similarly, a lower value was derived from these authors for the ACC $\left(0.09 \mathrm{~g} \mathrm{C} \mathrm{m}^{-2} \mathrm{~d}^{-1}\right)$ compared to the mean of $0.54 \mathrm{~g} \mathrm{C} \mathrm{m}^{-2} \mathrm{~d}^{-1}$ in the present study for the transect stations south of the PF. In contrast, the mean production derived by Mathot et al. (1992) from the ACC at $47^{\circ}$ and $49^{\circ} \mathrm{W}(0.55 \mathrm{~g} \mathrm{C}$ $\mathrm{m}^{-2} \mathrm{~d}^{-1}$ ) in December 1988 agreed closely with the corresponding value for the present study. However, samples taken from both ACC and Weddell Sea water from a $6^{\circ} \mathrm{W}$ transect in November 1992 (Jochem et al. 1995) gave consistently lower values in the range 0.2 to $0.3 \mathrm{~g} \mathrm{C}$ $\mathrm{m}^{-2} \mathrm{~d}^{-1}$, highlighting the variability recorded for the region. Although Rönner et al. (1983) demonstrated daily production of the order of $1 \mathrm{~g} \mathrm{C} \mathrm{m}^{-2} \mathrm{~d}^{-1}$ in the Weddell-Scotia Confluence based on ${ }^{15} \mathrm{~N}$ uptake measurements, values obtained from open waters of the Scotia Sea were observed to decrease to $0.2-0.3 \mathrm{~g} \mathrm{C} \mathrm{m}^{-2}$ $\mathrm{d}^{-1}$ eastwards towards South Georgia. Comparable values in late summer quoted by El-Sayed $\&$ Weber (1982) for the Scotia Sea were in the range 0.1 to $0.3 \mathrm{~g} \mathrm{C} \mathrm{m}^{-2} \mathrm{~d}^{-1}$, although these authors indicate that isolated high values may also be observed. From the present data set, it thus appears that production in the waters immediately adjacent to the South Georgia land-mass are generally higher than in the adjacent upstream and downstream open ocean waters. This is consistent with the elevated biomass observed both from ship-based studies and more recently by satellite ocean-colour measurements. Data from the SeaWiFS ocean colour sensor suggest that phytoplankton may be concentrated along the northern side of the island between December and March (Atkinson et al. 2001). Here the potential growing season is likely to be of the order of 4 mo with phytoplankton biomass commonly around $2 \mathrm{mg}$ chl $\mathrm{a} \mathrm{m}^{-3}$. This high phytoplankton productivity clearly has important implications for the

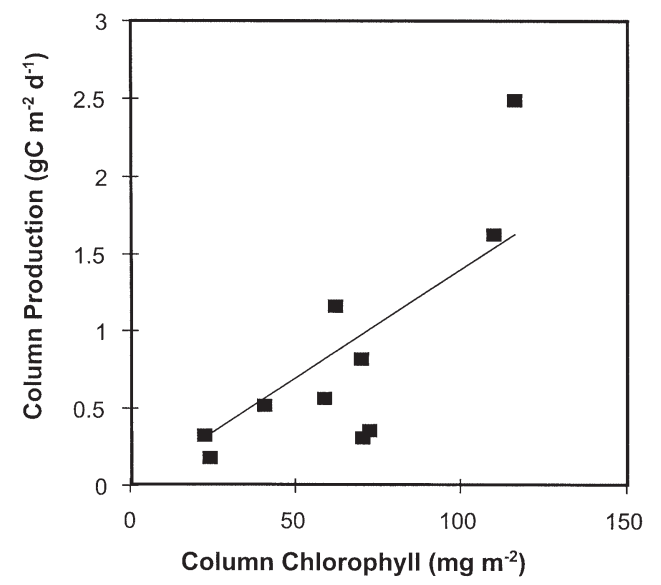

Fig. 4. Relationship between column production and column chl a concentration 
higher trophic levels of the local pelagic ecosystem in the vicinity of South Georgia.

\section{Photoinhibition}

A marked and consistent feature of the ${ }^{14} \mathrm{C}$ uptake data was the demonstration of photoinhibition. Since the samples were incubated under ambient, thus variable, irradiance conditions, we have not derived values of the parameter $\beta$, defined as the slope of the photoinhibited portion of the $P: I$ curve (Platt et al. 1980). We have quantified the influence of photoinhibition on column production by comparing the actual experimental data with theoretical values calculated using the value of maximum production $\left(P_{\max }\right)$ and assuming no photoinhibition. The reduction in column production ranged widely, from $3.9 \%$ at Stn MEB1 to $15.5 \%$ at Stn MEB10 (Fig. 3). These values lie within the range of inhibition of column production derived by Platt et al. (1990) from fundamental considerations.

Photoinhibition has frequently been observed in high latitude phytoplankton samples (e.g. Yamaguchi et al. 1985, Sakshaug \& Holm-Hansen 1986, Smith et al. 1991, Dower et al. 1996, Moline \& Prézelin 1997) and has generally been related to the magnitude of vertical mixing in the surface mixed layer inducing low light adaptation in the phytoplankton populations (Platt et al. 1982). It is possible that the degree of photoinhibition in the present observations has been enhanced by the extended incubation period to which the samples had been subject. However, the degree of photoinhibition in the sample incubated at $97 \%$ irradiance compared to $P_{\max }$ ranged between 40 and $80 \%$, similar to that recorded from other comparable high

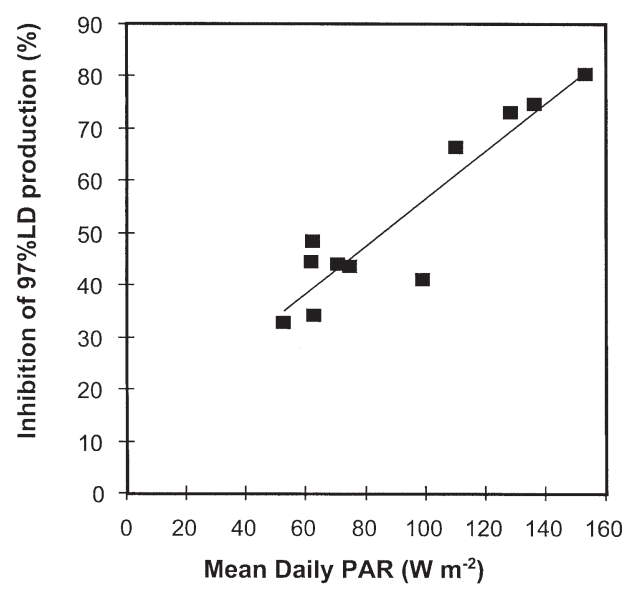

Fig. 5. Relationship between inhibition of carbon uptake for the sample incubated at $97 \%$ ambient irradiance and mean daily PAR latitude studies based on short-term constant irradiance incubations (Dower et al. 1996). The degree of photoinhibition was linearly related to ambient PAR $\left(r^{2}=0.86 ; n=11 ; p<0.001\right.$ Fig. 5). A similar relationship was noted previously by Takahashi et al. (1971). Although photoinhibition experienced by the surface phytoplankton samples under constant irradiance may be severe, the overall influence on column production estimates is limited.

\section{Primary production in relation to South Georgia food web fluxes}

The mean daily production rate across all stations was $0.80 \mathrm{~g} \mathrm{C} \mathrm{m}^{-2} \mathrm{~d}^{-1}$ with highest rates to the northwest of South Georgia and lowest to the east. These values are fairly high for the Southern Ocean, but not in a global context. However, the South Georgia region supports a productive pelagic ecosystem and major fisheries (see Hardy \& Gunther 1935, Everson 1984, Atkinson et al. 2001). Phytoplankton blooms north of South Georgia are often apparent from satellite data in spring and summer, and this may help to explain the high biomass (20 to $40 \mathrm{~g}$ fresh mass [FM] m ${ }^{-2}$ ) of metazoan zooplankton (metazooplankton) typical of the region in summer (Atkinson et al. 2001). This in turn is assumed to support a high biomass of apex predators.

The high biomass of consumers in the South Georgia pelagic system has been known for a long time, but there is uncertainty over the relative importance of advection and local production in sustaining this (Marr 1962, Croxall et al. 1985, Trathan et al. 1995, Atkinson et al. 2001). This study has added to the sparse data currently available on primary production in this system, and allows an appraisal of whether the locally enhanced production is significant compared to consumer demands.

\section{Carbon flux to grazers}

The metazooplankton grazers comprise a variety of taxonomic groups, but copepods and euphausiids predominate in terms of biomass. The copepods are represented by a large number of species, whilst Antarctic krill, Euphausia superba, may contribute more than half of the metazooplankton biomass. Krill do not appear to breed around South Georgia (Marr 1962, Ward et al. 1990) and the population is maintained by advection of animals from breeding populations around the Antarctic Peninsula and WeddellScotia area (Marr 1962, Hofmann et al. 1998, Murphy et al. 1998). This recruitment process exhibits marked interannual variability, giving rise to significant 
Table 3. Parameter values used to estimate carbon demand by krill and copepods in the South Georgia pelagic ecosystem (derived values are shown in bold)

\begin{tabular}{|c|c|c|c|}
\hline Parameter or variable & Units & Krill & Copepods \\
\hline Biomass, fresh mass & $\left(\mathrm{g} \mathrm{FM} \mathrm{m}^{-2}\right)$ & 30 & 20 \\
\hline Convert fresh mass to dry mass (DM/FM) & - & $0.235^{\mathrm{a}}$ & $0.235^{\mathrm{a}}$ \\
\hline Convert dry mass to carbon (C/DM) & - & $0.4^{\mathrm{a}}$ & $0.45^{\mathrm{b}}$ \\
\hline Biomass, as carbon & $\left(\mathrm{g} \mathrm{C} \mathrm{m}^{-2}\right)$ & 2.8 & 2.1 \\
\hline Assimilation efficiency & - & $0.85^{\mathrm{c}}$ & $0.85^{\mathrm{d}}$ \\
\hline BMR (prop. body C) ${ }^{*}$ & $\left(\mathrm{~d}^{-1}\right)$ & $0.05^{\mathrm{e}}$ & $0.15^{\mathrm{f}}$ \\
\hline $\mathrm{C}$ required for $\mathrm{BMR}$ & $\left(\mathrm{g} \mathrm{C} \mathrm{m}^{-2} \mathrm{~d}^{-1}\right)$ & 0.17 & 0.37 \\
\hline Growth conversion efficiency & - & $0.85^{\mathrm{b}}$ & $0.85^{\mathrm{b}}$ \\
\hline Maximum growth rate (prop. body C) & $\left(\mathrm{d}^{-1}\right)$ & $0.035^{\mathrm{g}}$ & $0.1^{\mathrm{h}}$ \\
\hline $\mathrm{C}$ required for growth & $\left(\mathrm{g} \mathrm{C} \mathrm{m}^{-2} \mathrm{~d}^{-1}\right)$ & 0.14 & 0.25 \\
\hline Total C requirement & $\left(\mathrm{g} \mathrm{C} \mathrm{m}^{-2} \mathrm{~d}^{-1}\right)$ & 0.31 & 0.62 \\
\hline \multicolumn{4}{|c|}{${ }^{a}$ Values derived from data compiled by Whitehouse et al. (1999) } \\
\hline \multicolumn{4}{|c|}{${ }^{\mathrm{b}}$ Compilation of unpublished BAS data } \\
\hline \multicolumn{4}{|c|}{${ }^{\mathrm{C}}$ Maximum assimilation rate estimated from Pond et al. (1995) } \\
\hline \multicolumn{4}{|c|}{ d'Maximum assimilation rate estimated from Schnack et al. (1985) } \\
\hline \multicolumn{4}{|c|}{${ }^{\mathrm{e}}$ Based on $\mathrm{C}$ ration at low phytoplankton concentration near South Georgia (Pakhomov et al. 1997a) } \\
\hline \multicolumn{4}{|c|}{${ }^{\mathrm{f}}$ Averaged value for a range of Antarctic copepod taxa (Schnack et al. 1985, Atkinson 1996) } \\
\hline \multicolumn{4}{|c|}{${ }^{9}$ Based on estimates of krill growth at South Georgia (Clarke \& Morris 1983, Reid 2001) } \\
\hline \multicolumn{4}{|c|}{${ }^{\mathrm{h}}$ Mean of direct measurements on copepodite stages of 2 species (Shreeve \& Ward 1998) } \\
\hline${ }^{*}$ Body C-ration for zero growth, expresse & on of body & & \\
\hline
\end{tabular}

changes in the composition of the metazooplankton community. Krill and copepods also interact directly, either through competition for food or through predation (Atkinson et al. 1999). Evidence from three surveys indicates that total metazooplankton biomass at South Georgia varied only slightly between years (Atkinson et al. 1999), but krill biomass is known to vary 10-fold (Brierley et al. 1999). Here we estimate the $\mathrm{C}$ flux to a metazooplankton community, the composition of which represents the average values derived from several repeat surveys; krill biomass $30 \mathrm{~g} \mathrm{FM} \mathrm{m}^{-2}$ (Brierley et al. 1999) and copepod biomass 20 g FM m$^{-2}$ (Pakhomov et al. 1997b, Atkinson et al. 1999, Ward \& Shreeve 1999).

Measured values for physiological rates (Table 3) have been used to derive 2 values for $\mathrm{C}$ demand for this metazooplankton community-one for the maintenance of 'basal metabolism' alone (here defined as the $\mathrm{C}$ intake to balance respiration loss when growth is zero), and a second to sustain maximum growth rate. The $\mathrm{C}$ required to maintain the basal metabolic rate (BMR) of krill biomass of $30 \mathrm{~g} \mathrm{FM} \mathrm{m}^{-2}\left(2.8 \mathrm{~g} \mathrm{C} \mathrm{m}^{-2}\right)$ is estimated to be $0.17 \mathrm{~g} \mathrm{C} \mathrm{m}^{-2} \mathrm{~d}^{-1}$ with a further $0.14 \mathrm{~g} \mathrm{C}^{-}$ $\mathrm{m}^{-2} \mathrm{~d}^{-1}$ required to support maximum growth. For a copepod biomass of $20 \mathrm{~g} \mathrm{FM} \mathrm{m}^{-2}\left(2.1 \mathrm{~g} \mathrm{C} \mathrm{m}^{-2}\right)$, BMR consumes $0.37 \mathrm{~g} \mathrm{C} \mathrm{m}^{-2} \mathrm{~d}^{-1}$ whilst maximum growth would consume a further $0.25 \mathrm{~g} \mathrm{C} \mathrm{m}^{-2} \mathrm{~d}^{-1}$. These values yield a gross growth efficiency (i.e. production divided by $\mathrm{C}$ intake) at maximum growth rate of 0.33 , a reasonable value.
These estimates of C uptake by grazers can be compared with values of primary production to examine whether locally enhanced primary production may be a significant factor in the enhanced food web fluxes at South Georgia. The total $\mathrm{C}$ requirement estimated for BMR of metazooplankton is $\sim 0.5 \mathrm{~g} \mathrm{C} \mathrm{m}^{-2} \mathrm{~d}^{-1}$, lower than the mean primary production rate of $0.8 \mathrm{~g} \mathrm{C} \mathrm{m}^{-2}$ $\mathrm{d}^{-1}$. Likewise, the estimate for maximum growth is $\sim 0.9 \mathrm{~g} \mathrm{C} \mathrm{m}^{-2} \mathrm{~d}^{-1}$, lower than the regional maximum average primary production of $1.5 \mathrm{~g} \mathrm{C} \mathrm{m}^{-2} \mathrm{~d}^{-1}$. Obviously this is a simple and crude comparison. Only a proportion of the total $\mathrm{C}$ rations of zooplankton is phytoplankton (Hopkins \& Torres 1989, Atkinson \& Snÿder 1997, Pakhomov et al. 1997a) and conversely there are other, unmeasured sinks of phytoplankton such as grazing by microzooplankton (Burkill et al. 1995) or sedimentation. The point we are making is that the values of $\mathrm{C}$ uptake and removal are of the same magnitude, implying that autochthonous production is important in supporting the substantial grazer biomass at South Georgia.

The values used for the physiological parameters obviously influence the $\mathrm{C}$ demand calculations. South Georgia data have been used where available and where extrapolations are made, for example, in the case of BMR, we have used data at the high-end of the spectrum of published literature values. Using lower values reduces grazer carbon demand, reinforcing our conclusion that locally high primary production is a significant factor in sustaining consumers. 
a)

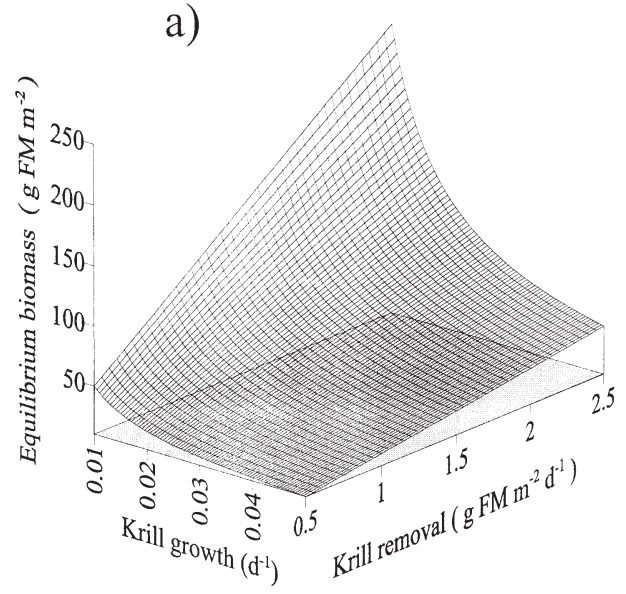

b)

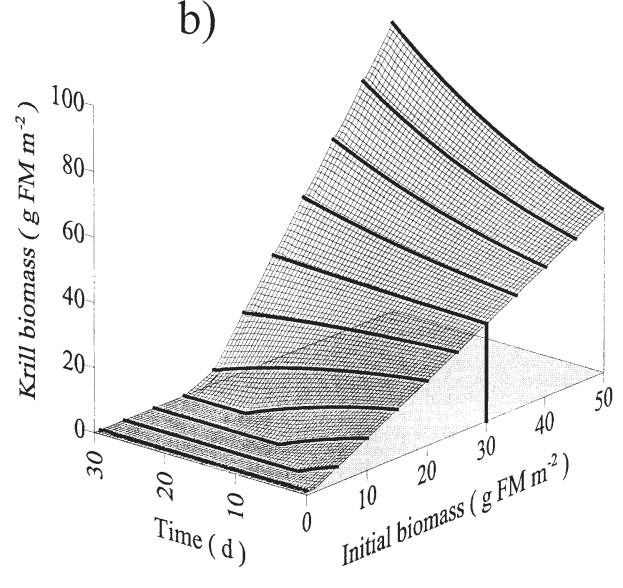

Fig. 6. Relationship between krill biomass, krill growth rate and rate of removal by predators: (a) contour plot of equilibrium biomass (at which production equals removal-see text) for a range of rates of proportionate growth rate $\left(\%\right.$ biomass $\left.\mathrm{d}^{-1}\right)$ and removal by predators; (b) time course, over $30 \mathrm{~d}$, of krill biomass for a range of initial biomass levels (0 to $50 \mathrm{~g}$ fresh mass [FM] $\mathrm{m}^{-2}$ ), at a production rate of $3.5 \%$ biomass $\mathrm{d}^{-1}$ and predator removal of $1 \mathrm{~g} \mathrm{FM} \mathrm{m}^{-2} \mathrm{~d}^{-1}$. Note that biomass neither increases nor decreases over the $30 \mathrm{~d}$ simulation for initial biomass $30 \mathrm{~g} \mathrm{FM} \mathrm{m}^{-2}$

\section{Carbon flux to predators}

Land-breeding birds and seals are a conspicuous element of the pelagic ecosystem around South Georgia and they act as predators at various levels in the island-ocean ecosystem. Indeed, it was their abundance in such areas which helped perpetuate the now discredited view of the entire Southern Ocean as a highly productive system. A feature of the biology of landbreeding predators is the closely circumscribed foraging range during the breeding season, determined by the need to be able to return to feed offspring (Murphy 1995, Croxall et al. 1999). This means that the C demand of breeding adults can be allocated to a specific area, and also that they are very sensitive to any major changes within their foraging range (Croxall et al. 1988). Boyd \& Croxall (1996) estimated that the annual food requirement of South Georgia bird and seal predators is $1.6 \times 10^{7} \mathrm{t} \mathrm{FM} \mathrm{yr}^{-1}$ or about $1.6 \times 10^{12} \mathrm{~g} \mathrm{C} \mathrm{Yr}^{-1}$.

This annual average value conceals considerable within-year variability in the local $\mathrm{C}$ demand of landbreeding predators. Demand for food is increased, and the average foraging area diminished, in the middle of the breeding season when the adult population is feeding close to the colony to provide food for themselves and their young. In a recent krill budget calculation, Atkinson et al. (2001) estimated removal of krill by fur seals and macaroni penguins at the major colonies to the northwestern end of the island alone, of the order of $32 \times 10^{3} \mathrm{t} \mathrm{FM} \mathrm{d}^{-1}\left(3 \times 10^{9} \mathrm{~g} \mathrm{C} \mathrm{d}^{-1}\right)$ in January. Atkinson et al. (2001) base their calculation on an area extending tens of kilometres from the colony, which encompasses most of the foraging range of the 2 predator species and has an area of the order of
$41000 \mathrm{~km}^{2}\left(4.1 \times 10^{10} \mathrm{~m}^{2}\right)$. Their best estimate for krill removal in this region at the time of peak demand is thus $\sim 1 \mathrm{~g} \mathrm{FM} \mathrm{m}^{-2} \mathrm{~d}^{-1}\left(\sim 0.1 \mathrm{~g} \mathrm{C} \mathrm{m}^{-2} \mathrm{~d}^{-1}\right)$.

The question is whether this rate of krill removal can be sustained by local production, or whether it is dependent on continual input of krill biomass through advection. We can calculate the biomass of krill for which production equals removal by predators, for a range of possible production and removal rates. The equilibrium biomass of krill, $B_{\text {equil }}\left(\mathrm{g} \mathrm{FM} \mathrm{m}^{-2}\right)$, is related to proportionate growth rate, PGR $\left(\mathrm{d}^{-1}\right)$, and biomass removal by predators, $R_{\text {pred }}\left(\mathrm{g} \mathrm{FM} \mathrm{m} \mathrm{F}^{-2} \mathrm{~d}^{-1}\right)$, by

Then

$$
B_{\text {equil }} \times \mathrm{PGR}=R_{\text {pred }}
$$

$$
B_{\text {equil }}=\frac{R_{\text {pred }}}{\text { PGR }}
$$

A contour plot of equilibrium biomass for a range of rates of growth $\left(1-5 \%\right.$ biomass $\left.\mathrm{d}^{-1}\right)$ and removal by predators $\left(0.5-2.5 \mathrm{~g} \mathrm{FM} \mathrm{m}^{-2} \mathrm{~d}^{-1}\right)$ shows that a best estimate value of krill predation of $1 \mathrm{~g} \mathrm{FM} \mathrm{m}^{-2} \mathrm{~d}^{-1}$ and maximum production of $3.5 \%$ biomass $\mathrm{d}^{-1}$ (values measured at South Georgia by Clarke \& Morris 1983, Reid 2001) can be sustained by a krill biomass of at least $30 \mathrm{~g} \mathrm{FM} \mathrm{m}^{-2}$ (Fig. 6a). This krill biomass corresponds to that of our 'typical' metazooplankton community used previously to estimate grazer $\mathrm{C}$ demand. Having indicated that primary production in the region of maximum predator feeding to the NW of South Georgia was potentially sufficient to sustain maximum production of both krill and copepods, these calculations suggest that the krill biomass produced under such conditions may be sufficient to support typical predator demands. 
Interannual changes in krill biomass provide an indication of the relationship between krill availability and the success of krill-dependent predators. There appears to be a threshold krill biomass below which predator demand cannot be fully supported, and measures of predator feeding and reproductive success decline (Boyd \& Murray in press). This critical value for krill biomass is ca. $30 \mathrm{~g} \mathrm{FM} \mathrm{m}^{-2}$, which is, perhaps not coincidentally, the mean value of krill biomass around the island (Brierley et al. 1999). We can visualise the relationship between production and predation for different initial krill biomass levels based on values of proportionate production $\left(3.5 \%\right.$ biomass $\mathrm{d}^{-1}$ at maximum growth rate) and predator removal (1 $\mathrm{g} \mathrm{FM} \mathrm{m}^{-2}$ $\mathrm{d}^{-1}$ ) used previously (Fig. 6b). This shows that, assuming these rates of krill removal and production, a krill biomass of at least $30 \mathrm{~g} \mathrm{FM} \mathrm{m}^{-2}$ would be sustained or experience net growth. However, when krill biomass is less than this critical value, predation exceeds production. This is a simplistic calculation, but is compatible with observation of krill and predator dynamics over more than a decade in a region exhibiting strong interannual variability.

\section{SUMMARY AND CONCLUSIONS}

Primary production measured during summer in several regions around South Georgia and near the Antarctic PF varied from 0.34 to $1.52 \mathrm{~g} \mathrm{C} \mathrm{m}^{-2} \mathrm{~d}^{-1}$. The highest regional rates (mean 1.52, range 0.9 to $2.5 \mathrm{~g} \mathrm{C}$ $\mathrm{m}^{-2} \mathrm{~d}^{-1}$ ) were recorded at stations to the northwest of the island. Photoinhibition of production in the near-surface layer decreased column production by 4 to $16 \%$.

Estimates of $\mathrm{C}$ demand by the 2 main groups of metazooplankton-Antarctic krill and copepodssuggest that $\sim 0.5 \mathrm{~g} \mathrm{C} \mathrm{m}^{-2} \mathrm{~d}^{-1}$ would be needed to sustain basal metabolism. This value is less than the measured primary production rate at most stations around South Georgia. Combined C demand for the 2 groups at maximum growth rate was estimated to be $0.93 \mathrm{~g} \mathrm{C}$ $\mathrm{m}^{-2} \mathrm{~d}^{-1}$; primary production rates higher than this were only found in more productive regions to the northwest of the island.

Maintenance of the krill population at South Georgia appears to depend on advection of animals from higher latitudes. This krill stock supports large populations of predators. However, the degree to which the food supply for predators is replenished by advection and how much is provided by local krill production has been uncertain. Taking typical values for removal rates of krill by predators, and krill production rates and biomass, we suggest that krill production may equal or exceed the predator demand under some conditions.
When krill biomass exceeds the long-term mean value of $\sim 30 \mathrm{~g} \mathrm{FM} \mathrm{m}^{-2}$ (Brierley et al. 1999), we calculate that growth at the maximum rate used in our calculations $\left(3.5 \%\right.$ body mass $\left.\mathrm{d}^{-1}\right)$ is adequate to sustain removal by predators. Combining this with our estimates of $\mathrm{C}$ demand by metazooplankton suggests that primary production measured in this study met the requirements for maximum growth rate at some stations.

Our observations and calculations support those of Atkinson et al. (2001) that autochthonous production can make a significant contribution to the South Georgia food web. Our estimate of optimal krill biomass based on production criteria agrees with the threshold value for breeding success by krill-dependent, landbased predators (Boyd \& Murray 2001). This and the co-location of the region of highest homoiothermic predator foraging with the highest primary production in this study may point to complex relationships within the local system (cf. Whitehouse et al. 1999, Atkinson et al. 2001).

\section{LITERATURE CITED}

Allanson BR, Hart RC, Lutjeharms JRE (1981) Observations on the nutrients, chlorophyll and primary production of the Southern Ocean south of Africa. S Afr J Antarct Res 10/11:3-14

Atkinson A (1996) Sub-Antarctic copepods in an oceanic, low chlorophyll environment: ciliate predation, food selectivity and impact on prey populations. Mar Ecol Prog Ser 130: $85-96$

Atkinson A, Snÿder R (1997) Krill-copepod interactions at South Georgia, Antarctica. I. Omnivory by Euphausia superba. Mar Ecol Prog Ser 160:63-76

Atkinson A, Ward P, Hill A, Brierley AS, Cripps GC (1999) Krill-copepod interactions at South Georgia, Antarctica. II. Euphausia superba as a major control on copepod abundance. Mar Ecol Prog Ser 176:63-79

Atkinson A, Whitehouse MJ, Priddle J, Cripps GC, Ward P, Brandon MA (2001) South Georgia, Antarctica: a productive, cold water pelagic ecosystem. Mar Ecol Prog Ser 216: 279-308

Blain S, Tréguer P, Belviso S, Bucciarelli E and 8 others (2001) A biogeochemical study of the island mass effect in the context of the iron hypothesis: Kerguelen Islands, Southern Ocean. Deep-Sea Res 48:163-187

Blight SP (1997) Microbial metabolism and temperature: comparative studies in the Southern Ocean and a temperate coastal ecosystem. PhD thesis, University of Wales, Bangor

Boyd IL, Croxall JP (1996) Dive durations in pinnipeds and seabirds. Can J Zool 74:1696-1705

Boyd IL, Murray AWA (in press) Monitoring a marine ecosystem using responses of upper trophic level predators. J Anim Ecol 70:747-760

Brandon MA, Murphy EJ, Whitehouse MJ, Trathan PN, Murray AWA, Bone D, Priddle J (1999) The shelf-break front to the east of the sub-Antarctic island of South Georgia. Cont Shelf Res 19:799-819

Brierley AS, Watkins JL, Goss C, Wilkinson MT, Everson I (1999) Acoustic estimates of krill density at South Georgia 1981 to 1998. CCAMLR Sci 6:47-57

Burkill PH, Edwards ES, Sleigh MA (1995) Microzooplankton 
and their role in controlling phytoplankton growth in the marginal ice-zone of the Bellingshausen Sea. Deep-Sea Res II 42:1277-1290

Clarke A, Morris DJ (1983) Towards an energy budget for krill: the physiology and biochemistry of Euphausia superba Dana. Polar Biol 2:69-86

Croxall JP, Prince PA, Ricketts C (1985) Relationships between prey life cycles and the extent, nature and timing of seal and seabird predation in the Scotia Sea. In: Siegfried WR, Condy PR, Laws RM (eds) Antarctic nutrient cycles and food webs. Springer, Berlin, p 516-533

Croxall JP, McCann TS, Prince PA, Rothery P (1988) Reproductive performance of seabirds and seals at South Georgia and Signy Island, South Orkney Islands, 1976-1987: implications for Southern Ocean monitoring studies. In: Sahrhage D (ed) Antarctic ocean and resources variability. Springer, Berlin, p 261-285

Croxall JP, Reid K, Prince PA (1999) Diet, provisioning and productivity responses of marine predators to differences in availability of Antarctic krill. Mar Ecol Prog Ser 177: 115-131

Dierssen HM, Vernet M, Smith RC (2000) Optimizing models for remotely estimating primary production in Antarctic coastal waters. Antarct Sci 12:20-32

Dower KM, Lucas MI, Phillips R, Dieckmann G, Robinson DH (1996) Phytoplankton biomass, $P-I$ relationships and primary production in the Weddell Sea, Antarctica, during the austral autumn. Polar Biol 16:41-52

El-Sayed SZ, Weber LH (1982) Spatial and temporal variations in phytoplankton blooms and primary productivity in the Southwest Atlantic and the Scotia Sea. Polar Biol 1: 83-90

Everson I (1984) Marine interactions. In: Laws RM (ed) Antarctic ecology, Vol. 2. Academic Press, London, p 783-819

Fenton N (1991) Influence of physical environment on production and distribution of Antarctic phytoplankton. PhD thesis, University of Wales, Bangor

Fenton N, Priddle J, Tett P (1994) Regional variations in biooptical properties of the surface waters in the Southern Ocean. Antarct Sci 6:443-448

Hardy AC, Gunther ER (1935) The plankton of the South Georgia whaling grounds and adjacent waters, 1926-1927. Discovery Rep 11:1-456

Heywood RB, Priddle J (1987) Retention of phytoplankton by an eddy. Cont Shelf Res 7:937-955

Hofmann EE, Klinck JM, Locarnini RA, Fach B, Murphy EJ (1998) Krill transport in the Scotia Sea and environs. Antarctic Sci 10:406-415

Hopkins TL, Torres JJ (1989) The zooplankton community in the vicinity of the ice edge, western Weddell Sea, March 1986. Polar Biol 9:93-106

Jochem J, Mathot S, Quéguiner B (1995) Size-fractionated primary production in the open Southern Ocean in austral spring. Polar Biol 15:381-392

Longhurst A, Sathyendranath S, Platt T, Caverhill C (1995) An estimate of global primary production in the ocean from satellite radiometer data. J Plankton Res 17:1245-1271

Marr JWS (1962) The natural history and geography of the Antarctic krill (Euphausia superba Dana). Discovery Rep 32:33-464

Mathot S, Dandois JM, Lancelot C (1992) Gross and net primary production in the Scotia-Weddell Sea sector of the Southern Ocean during spring 1988. Polar Biol 12:321-332

Mitchell BG, Holm-Hansen O (1991) Bio-optical properties of Antarctic Peninsula waters differentiation from temperate ocean models. Deep-Sea Res 38:1009-1028

Moline MA, Prézelin BB (1997) High-resolution time-series data for 1991/1992 primary production and related parameters at a Palmer LTER coastal site: implications for modelling carbon fixation in the Southern Ocean. Polar Biol 17 $39-53$

Murphy EJ (1995) Spatial structure of the Southern Ocean ecosystem-predator-prey linkages in Southern Ocean food webs. J Anim Ecol 64:333-347

Murphy EJ, Watkins JL, Reid K, Trathan PN and 6 others (1998) Interannual variability of the South Georgia marine ecosystem: biological and physical sources of variation in the abundance of krill. Fish Oceanogr 7:381-390

Owens NJP, Priddle J, Whitehouse MJ (1991) Variations in phytoplanktonic nitrogen assimilation around South Georgia and in the Bransfield Strait (Southern Ocean). Mar Chem 35:287-304

Pakhomov EA, Perissinotto R, Froneman PW, Miller DGM (1997a) Energetics and feeding dynamics of Euphausia superba in the South Georgia region during the summer of 1994. J Plankton Res 19:399-423

Pakhomov EA, Verheye HM, Atkinson A, Laubscher RK, Taunton-Clark J (1997b) Structure and grazing impact of the mesozooplankton community during late summer 1994 near South Georgia, Antarctica. Polar Biol 18:180-192

Parsons TR, Maita Y, Lalli CM (1984) A manual of chemical and biological methods for seawater analysis. Pergamon Press, Oxford

Perissinotto R, Lutjeharms JRE, van Ballegooyen RC (2000) Biological-physical interactions and pelagic productivity at the Prince Edward Islands, Southern Ocean. J Mar Syst $24: 327-341$

Platt T, Gallegos CL, Harrison WG (1980) Photoinhibition of photosynthesis in natural assemblages of marine phytoplankton. J Mar Res 38:687-701

Platt T, Harrison WG, Irwin B, Horne EP, Gallegos CL (1982) Photosynthesis and photoadaptation of marine phytoplankton in the Arctic. Deep-Sea Res 29:1159-1170

Platt T, Sathyendranath S, Ravindran P (1990) Primary production by phytoplankton: analytic solutions for daily rates per unit area of water surface. Proc Roy Soc Lond B 241: 101-111

Pond DJ, Priddle J, Sargent J, Watkins JL (1995) Laboratory studies of the character and time course of assimilation and egestion of algal lipid by Antarctic krill. J Exp Mar Biol Ecol 187:253-268

Priddle J, Leakey R, Symon C, Whitehouse M, Robins D, Cripps G, Murphy E, Owens N (1995) Nutrient cycling by Antarctic marine microbial plankton. Mar Ecol Prog Ser 116:181-198

Priddle J, Boyd IL, Whitehouse MJ, Murphy EJ, Croxall JP (1998) Estimates of Southern Ocean primary productionconstraints from predator carbon demand and nutrient drawdown. J Mar Syst 17:275-288

Reid K (2001) Growth of Antarctic krill Euphausia superba at South Georgia. Mar Biol 138:57-62

Rönner U, Sorensson F, Holm-Hansen O (1983) Nitrogen assimilation by phytoplankton in the Scotia Sea. Polar Biol $2: 137-147$

Sakshaug E, Holm-Hansen O (1986) Photoadaptation in Antarctic phytoplankton: variations in growth rate, chemical composition and $P$ versus $I$ curves. J Plankton Res 8: $459-473$

Savidge G, Gilpin LC (1999) Seasonal influences on sizefractionated chlorophyll a concentration and primary production in the north-west Indian Ocean. Deep-Sea Res II 46:701-723

Savidge G, Harbour D, Gilpin LC, Boyd PW (1995) Phytoplankton distributions and production in the Bellings- 
hausen Sea, Austral spring 1992. Deep-Sea Res II 42: 1201-1224

Schnack SB, Smetacek V, von Bodungen B, Stegmann P (1985) Utilization of phytoplankton by copepods in Antarctic waters during spring. In: Gray JS, Christiansen $\mathrm{ME}$ (eds) Marine biology of polar regions and the effects of stress on marine organisms. Wiley, London, p 65-81

Shreeve RS, Ward P (1998) Moulting and growth of the early stages of two species of Antarctic calanoid copepods in relation to differences in food supply. Mar Ecol Prog Ser 175:109-119

Smetacek V, Scharek R, Gordon LI, Eicken H, Fahrbach E, Rohardt G, Moore S (1992) Early spring phytoplankton blooms in ice platelet layers of the Southern Weddell Sea, Antarctica. Deep-Sea Res 39:153-168

Smith WO, Gordon LI (1997) Hyperproductivity of the Ross Sea (Antarctica) polynya during austral spring. Geophys Res Lett 24:233-236

Smith WO, Brightman RI, Booth BC (1991) Phytoplankton biomass and photosynthetic response during the winterspring transition in the Fram Strait. J Geophys Res 96: 4549-4554

Takahashi M, Shimura S, Yamaguchi Y, Fujita Y (1971) Photoinhibition of phytoplankton photosynthesis as a function of exposure time. J Oceanogr Soc Jpn 27:43-50

Trathan P, Everson I, Miller DGM, Watkins JL (1995) Krill biomass in the Atlantic. Nature 373:201-202

Trathan P, Brandon MA, Murphy EJ (1997) Characterization of the Antarctic Polar Frontal Zone to the north of South Georgia in summer 1994. J Geophys Res 102:10483-10497

Trathan PN, Brandon MA, Murphy EJ (2000) Transport and structure within the Antarctic Circumpolar Current to the

Editorial responsibility: Otto Kinne (Editor),

Oldendorf/Luhe, Germany north of South Georgia. Geophys Res Lett 27:1727-1730

Ward P, Shreeve RS (1999) The spring mesozooplankton community at South Georgia: a comparison of shelf and oceanic sites. Polar Biol 22:289-301

Ward P, Atkinson A, Peck JM, Wood AG (1990) Euphausiid life cycles and distribution around South Georgia. Antarct Sci 2:43-52

Whitehouse MJ (1997) Automated seawater nutrient chemistry. British Antarctic Survey, Cambridge

Whitehouse MJ, Symon C, Priddle J (1993) Variations in the distribution of chlorophyll $a$ and inorganic nutrients around South Georgia, South Atlantic. Antarct Sci 5:367-376

Whitehouse MJ, Priddle J, Symon C (1996) Seasonal and annual change in seawater temperature, salinity, nutrient and chlorophyll a distributions around South Georgia, South Atlantic. Deep-Sea Res I 43:425-443

Whitehouse MJ, Priddle J, Brandon MA, Swanson C (1999) A comparison of chlorophyll/nutrient dynamics at two survey sites near South Georgia, and the potential role of planktonic nitrogen recycled by land-based predators. Limnol Oceanogr 44:1498-1508

Whitehouse MJ, Priddle J, Brandon MA (2000) Chlorophyll/ nutrient characteristics in the water masses to the north of South Georgia, Southern Ocean. Polar Biol 23:373-382

Wright SW, van den Enden RL (2000) Phytoplankton community structure and stocks in the East Antarctic marginal ice zone (BROKE survey, January-March 1996) determined by CHEMTAX analysis of HPLC pigment signatures. Deep-Sea Res II 47:2363-2400

Yamaguchi Y, Kosaki S, Aruga Y (1985) Primary productivity in the Antarctic Ocean during the austral summer of 1983/1984. Trans Tokyo Univ Fish 6:67-84

Submitted: August 23, 2001; Accepted: June 26, 2002

Proofs received from author(s): September 20, 2002 